\title{
A RING D CHROMOSOME IN ASSOCIATION WITH DOWN'S SYNDROME-LIKE PHENOTYPE
}

\author{
A. WAJNTAL * \\ A. J. Diament ** \\ P. H. SAldanHa *
}

The first ring chromosome was described by Morgan (1933) ${ }^{9}$ and originated from a crossing-over between attached X-chromosomes containing an inversion in Drosophila. Since then ring chromosome have been studied specially in Drosophila, maise and Man. Interest on ring chromosomes arises from the fact that some information may be disclosed regarding mechanism of chromatid splitting during mitosis and meiosis as well as on sister-strand crossing-over (McClintock, $1938^{7}$; Smith Whit $\epsilon^{\prime}$ et al., $1963^{10}$ ). In man, ring chromosomes might be valuable in assigning loci to specific chromosomes not only because of the original deletion involved in the formation of the ring but also because of the deficiencies and duplications that might arise during mitotic divisions (Lejeune, 1967) ${ }^{6}$. Thus, studying patients with a ring $\mathrm{D}$ chromosome, the locus that determines the synthesis of the alpha chain of haptoglobin has been shown to belong to the chromosome 13 (Gerald et al. ${ }^{4}$, 1967; Bloom et al. $^{2}$, 1967).

The present paper reports on a patient with Down's syndrome-like characteristics and whose caryotype analysis revealed a mosaicism involving a ring $\mathrm{D}$ chromosome.

\section{CASE REPORT}

S.F.B., white female born on 6-1-1959, admitted at the Clinical Hospital of the University of Săo Paulo in 20-6-65. She was the eighth pregnancy of a sibship with 4 brothers and 3 sisters being all healthy, except the third pregnancy that was a male stillbirth. The parents are not related and, at birth, her father was 44 and her mother 34 years old. The course and lenght of pregnancy were normal. Delivery was unremarkable. Birth weight was $1.800 \mathrm{~g}$. Neuromotor development during childhood was apparently normal, according to her mother's information. At clinical admission, because of the mongoloid aspect of her face, the patient was referred for neurological and genetical studies. The patient was reexamined when she was ten years old and her photographs taken at that time are shown in fig. 1 . There was light tympanic sound by cranial percussion and evolutional dyslalia. Physical reexamination at 11 years of age revealed height $1.60 \mathrm{~m}$, weight $44.5 \mathrm{~kg}$, span $1.57 \mathrm{~m}$, microcephaly, nose flattening, bilateral epicanthus, high-arched palate, bilateral strabismus, thoracic ciphosis, lombar lordosis, acne, light breast development, ulnar deflection of hands, light radial rotation (clinodactyly) of thumbs, long fingers

* Laboratório de Genética Médica e ** Departamento de Neuropsiquiatria, Faculdade de Medicina, Universidade de São Paulo.

Aknowledgements - The authors are deeply indebted to Mrs. Tiyo T. Matsuo, Mrs. Célia P. Koiffmann, Mrs. Betty Knobel and Miss Sueli B. Itskan for their technical assistance. 
resembling aracnodactyly, absence of pubic hair, and confirmed evolutional dyslalia and auditory deficit. Vertebral and hand X-rays examinations were normal. Mastoid and pyramidal X-ray films suggested bilateral increased lumen of the inner acoustic ducts and mastoidal pneumatization. Skull X-ray films were normal except for veiling of right antromaxilla and assymetry of right retro-pyramidal bone (maxillar sinusopathy). Psychological examination (Goodenough and Terman-Merrill) indicated $\mathrm{IQ}=57$ with childish language. Serum protein electrophoresis showed relative and absolute decrease of alpha globulin. Ishihara tests revealed normal color vision. Red cell G6PD activity was also normal (7.4 U.C1. B type).
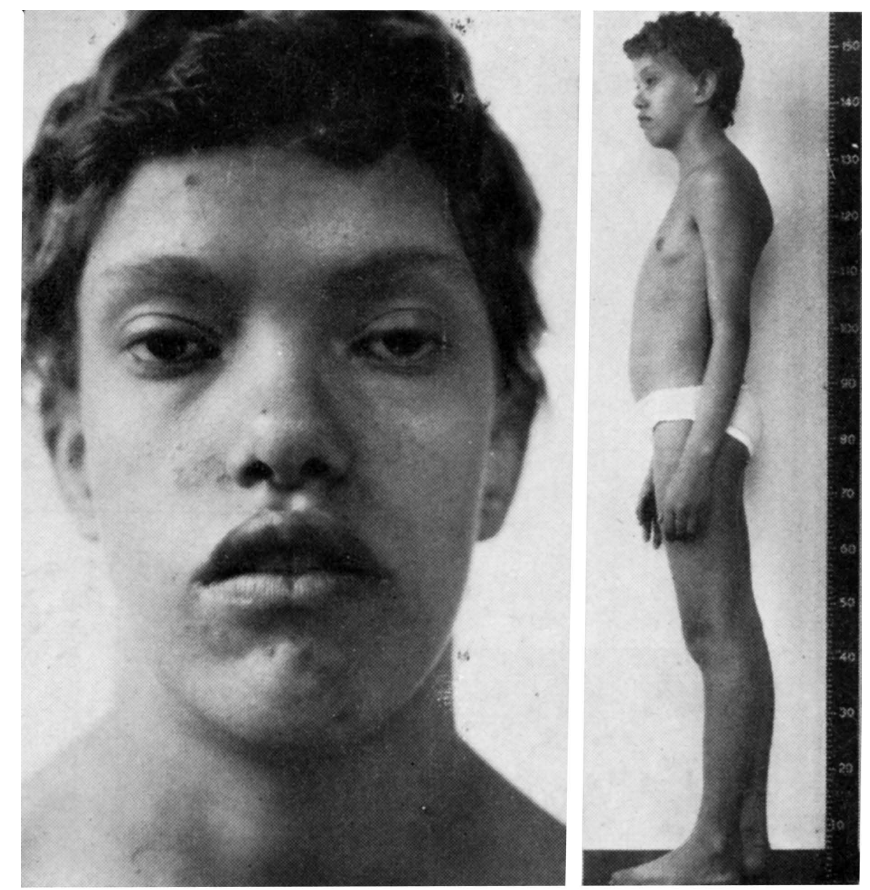

\section{Fig. 1 - Physical aspect of the patient S.F.B., face and whole body profile.}

Chromosome and dermatoglyphic studies - Chromosome study was carried out by a modified method based on Moorhead et al. (1960) ${ }^{8}: 0.1 \mathrm{ml}$ of heparinized peripheral blood were cultured in $60 \%$ of Hanks saline supplemented with $20 \%$ of a $2.5 \%$ lactoalbumin hidrolisate solution, $20 \%$ of calf serum, $0.5 \%$ Phytoclin *, $0.001 \%$ glicose and antibiotics. The cultures were incubated for 96 hours, treated with $1 \times 10^{-7} \mathrm{M}$ Colcemid (Ciba) and slides prepared by the air drying method.

Buccal smears for sex chromatin studies were fixed in 1:1 ethano-1:ether and Feulgen stained. Dermatoglyphics were taken by standard ink method.

Chromosome analysis of 30 metaphase plates revealed 28 cells with 46 chromosomes and normal female constitution (fig. 2) and 2 cells with 46 choromosomes and one chromosome missing in the D group (13-13) with the extra cromosome showing a ring-like appearence (fig. 3). Scoring for ring chromosomes in 60 cells of a second culture revealed 8 ring-bearing cells giving a total of 10 ring cells in

* Were are grateful to Laboratórios Burroghs-Wellcome do Brasil S.A. for furnishing Phytoclin. 


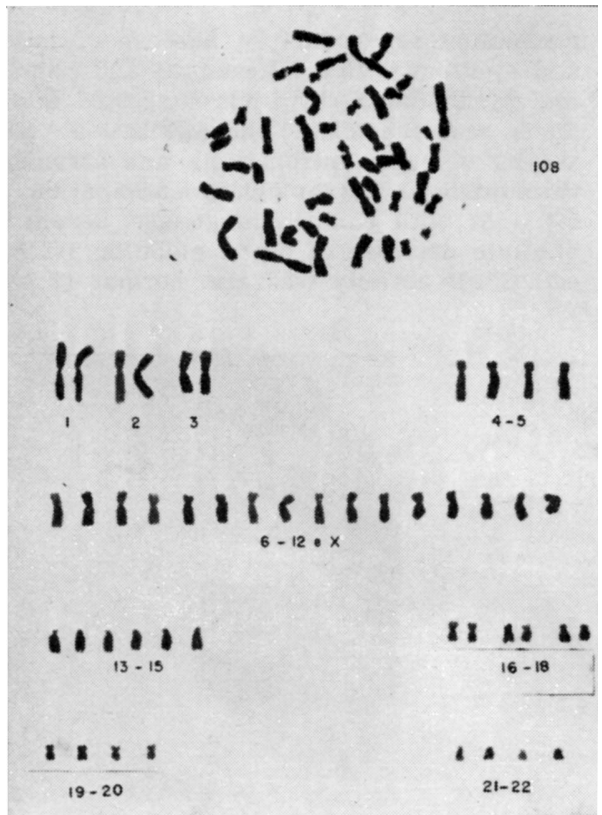

Fig. 2 - Karyotype of a cell of normal constitution, 46, XX.
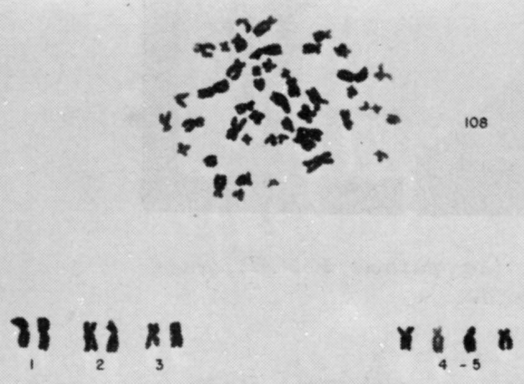

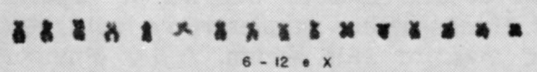

$\rightarrow \underset{13-15}{\wedge \rightarrow}:$

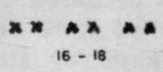

$=\frac{19-20}{19-20}$

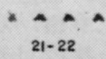

Fig. 3 - Karyotype of a cell, ring chromosome replacing one of the D-group. 


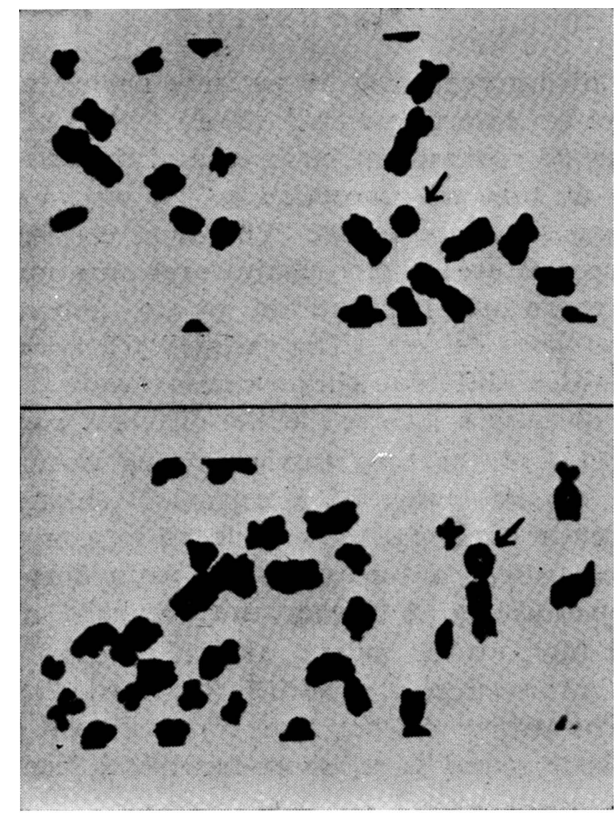

Fig. \& - Ring chromosome in two different mitoses.
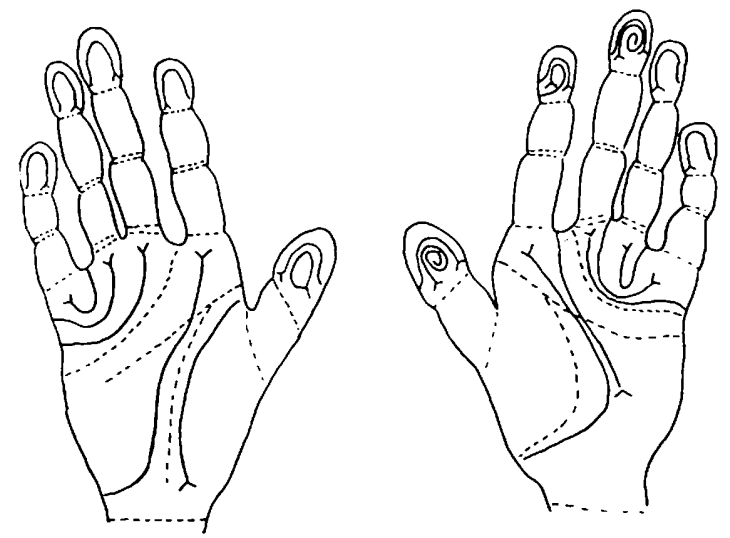

Fig. 5 - Digito-palmar dermatoglyphics.

90 mitoses. It was not found cells with two ring chromosomes or cells with 5 D chromosomes without any ring. The 10 ring chromosomes were of a uniform size and in the range of normal $\mathrm{D}$ chromosomes (fig. 4).

The patient had a normal nuclear sex with $20 \%$ of positive sex-chromatin nuclei.

There were some abnormalities in the dermal ridges: there were a radial loop on $R^{2}$, ulnar loops on $R^{3}, R^{4}, R^{5}, L^{4}$ and $L^{5}$ and whorles on the remaining finger. The total ridge count 149 was within normal female range. The axial triradius was displaced distally $(38,2 \%)$ on the right palm and was proximal $(15,7 \%)$ on the left palm. The right palm had an incomplete Sydney's line (fig. 5). 


\section{I S U S S I ON}

The clinical findings regarding 16 patients having a D-ring chromosome have been reviewed by Alderdice et al. ${ }^{1}$ (1969). Most of the parents of such children were below 25 years old at birth time of the affected child suggesting that parental age at time of conception is not an important factor in the origin of this chromosome aberration. The most common defects correlated with ring $\mathrm{D}$ chromosome are: microcephaly, large ears, epicanthic folds, ocular hipertelorism, micrognathia, high arched palate, abnormalities of external genitalia, congenital heart defects. The variability between the different cases might be due to either different chromosomes involved in the $\mathrm{D}$ group, or to deletions and duplications involved in the different ring chromosomes.

Though only $11 \%$ of the cells carried a ring chromosome and the size of the rings is in the size range of a normal $D$ chromosome, the patient's phenotype is suficiently abnormal to be included in a mongolism study. As a matter of fact, the patient has most of the main diagnostic characteristics for Down's syndrome: mental deficiency, microcephaly, epicanthic folds, small and low set ears, high arched palate, atipical palmar creases, clinodactyly of the 5th finger, displaced axial triradiis, increased distance between halux and second toe. The patient did not have a protuberant scrotal tongue, short bulky neck, hipoplastic nasal bone, short hand and feet, short stature or a typical mongoloid facies.

The clinical features of this patient were similar to those described by Jacobsen ${ }^{5}$ (1966) and Emberger et al. $^{3}$ (1971). All other cases of ring D chromosome were associated with a much more deviant phenotype. Both cases were disclosed to have the chromosome 15 involved in the ring formation. The replication pattern of the ring chromosome from patients herewith described has not been studied yet. As this patient has a low frequency of cells carrying the ring chromosome $(11 \%)$ it is rather difficult to establish whether the minor deviations involved are consequence of a mosaicism with a majority of normal cells or they are specific for rings involving chromosome 15 .

Unless it is assumed that part of a $G$ chromosome is included in the ring formation, what seems very unlikely, this case calls attention by the fact that the same abnormalities might be common to different chromosome aberrations. Whether this indicated that the normal phenotype for the abnormalities involved is conditioned by a large number of genes spread out on different chromosomes or alternatively, that the particular abnormalities might be caused by genic imbalance, common to any chromosomal aberration, is still an open question that will be answered only after more is known on the correlation between different chromosomal aberrations and the phenotypes abnormalities involved.

The case of a ten-years-old mentally retarded girl with Down's syndromelike features whose chromosome analysis revealed an unusual mosaicism including $10 \%$ mitosis with a ring chromosome replacing a $\mathrm{D}$ chromosome is 
reported. The clinical features of the patient were considered similar to those described by Jacobsen (1966) and Emberger et al. (1971) who interpreted the ring chromosome present in their patients as being chromosome 15 .

\section{R E U M O}

Relata-se um caso de uma menina com 10 anos de idade, mentalmente retardada e com semelhanças com a sindrome de Down, cuja análise cromossômica revelou um mosaicismo pouco freqüente, incluindo $10 \%$ de mitoses com um cromossoma em anel substituindo um cromossoma D. O quadro clínico da paciente é similar ao descrito por Jacobsen (1966) e Emberger et al. (1971) que interpretaram a presença do cromossoma em anel em seus pacientes como sendo o cromossoma 15.

\section{REFERENCIAS}

1. ALLDERICE, P. W.; DAVIS, J. G.; MILlER, O. J.; KLINGER, H. P.; WARBURTON, D.; MILLER, D. A.; ALLEN, F. H.; ABRAMS, C. A. L. \& MCGILlVRAY, E. - The 13q-deletion syndrome. Amer. J. hum. Genet. 21:499, 1969.

2. BLOOM, G. E.; GERALD, P. S. \& REISMAN, L. E. - Ring D chromosome: a second case associated with anomalous haptoglobin inheritance. Science 156: 1746, 1967.

3. EMBERGER, J. M.; ROSSI, D.; JEAN, R.; BONNET, H. \& DUMAS, R. - Etude d'une observation de chromosome des group 13-15 en anneau (46, XY, 15r). Humangenetik 11:295, 1971.

4. GERALD, P. S.; WARNER, S.; SINGER, J. D ;; CORCORAN, P. A. \& UMANSKY, I. - A ring D chromosome and anomalous inheritance of haptoglobin type J. Pediat. 70:172, 1967.

5. JACOBSEN, P. - A ring chromosome in the 13-15 group associated with microcephalic dwarfism, mental retardation and emotional immaturity. Hereditas 55: 188, 1966.

6. LEJEUNE, J. - La duplication de structures circulaires. Ann. Genet. 11:71, 1968.

7. MCCLINTOCK, B. - The production of homozygous deficient tissues with mutant characteristics by means of the aberrant mitotic behavior of a ring shaped chromosome. Genetics 23:315, 1938.

8. MOORHEAD, P. S.; NOWELL, P. C.; MELlMAN, W. J.; BATTIPS, D. M. \& HUNGERFORD, D. A. - Chromosome preparations of leukocytes cultured from human peripheral blood. Expt. Cell. Res. 20:613, 1960.

9. MORGAN, T. H. - A closed X chromosome in Drosophila melanogaster. Genetics 18:250, 1933.

10. SMITH WHITE, S.; PEACOCK, W. J.; TURNER, B. \& DEN DULK, G. M. A ring chromosome in man. Nature 197:102, 1963.

Laboratório de Genética Médica - Faculdade de Medicina da Universidade de São Paulo - P.O.Box 2921 - 01000 São Paulo, SP - Brasil. 